\title{
Performance Assessment of a Box Type Solar Cooker Using Jatropha Oil as a Heat Storage Material
}

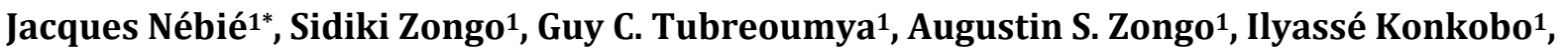 \\ Boubou Bagré1, Ali Diané1, Tizane Dahoํ, Serges W. Igo² ${ }^{2}$ Belkacem Zeghmati ${ }^{3}$, Antoine Béré1 \\ ${ }^{1}$ Laboratoire de Physique et de Chimie de l'Environnement (LPCE), Université Joseph Ki-Zerbo, Ouagadougou, Burkina Faso \\ ${ }^{2}$ Département Energie, Institut de Recherche en Sciences Appliquées et Technologies (IRSAT/CNRST), Ouagadougou, \\ Burkina Faso \\ ${ }^{3}$ Laboratoire de Mathématiques et Physique (LAMPS), Université de Perpignan Via Domitia, Perpignan, France \\ Email: ‘jacquesnbi@yahoo.fr
}

How to cite this paper: Nébié, J., Zongo, S., Tubreoumya, G.C., Zongo, A.S., Konkobo, I., Bagré, B., Diané, A., Daho, T., Igo, S.W., Zeghmati, B. and Béré, A. (2022) Performance Assessment of a Box Type Solar Cooker Using Jatropha Oil as a Heat Storage Material. Energy and Power Engineering, 14, 124-132.

https://doi.org/10.4236/epe.2022.142005

Received: December 16, 2021

Accepted: February 19, 2022

Published: February 22, 2022

Copyright $\odot 2022$ by author(s) and Scientific Research Publishing Inc. This work is licensed under the Creative Commons Attribution International License (CC BY 4.0).

http://creativecommons.org/licenses/by/4.0/ (c) (i) Open Access

\begin{abstract}
Solar cookers are a good option in developing countries with high solar potential for environmentally friendly cooking and reduced pressure on forests. However, they are still affected by the intermittency of the sun. In order to overcome this problem, in this work, a box type solar cooker integrated Jatropha oil as a heat storage material is fabricated and experimented with. The design was examined with a maximum stagnation temperature of $157.7^{\circ} \mathrm{C}$. The recorded cooking power vanished between 78.4 and $103.6 \mathrm{~W}$, while thermal efficiency varied from $41.26 \%$ to $58.78 \%$. The energy transfer cycle test, including charge and discharge revealed that $91.18 \%$ of the heat lost through the cooker could be recovered by the heat storage unit and a large amount is restored to the system during cloudiness or a temperature perturbation.
\end{abstract}

\section{Keywords}

Solar Cooker, Kapok Wool, Performance, Heat Storage, Jatropha Oil

\section{Introduction}

The energy requirements in developing countries for cooking represent about $30 \%$ of global energy consumption [1]. About 2.7 billion people rely on traditional biomass for cooking [2]. Specifically, Woody biomass represents nearly $81 \%$ of energy consumption in Sub-Saharan Africa [3]. This large dependence on traditional biomass is source of air pollution, deforestation and greenhouse 
gas emission contributes as a factor in climate change and source of millions of deaths worldwide, particularly among women and children [4]. Likely, Sub-Saharan countries are largely exposed to solar radiation as alternative and attractive options for domestic use. The sector of solar cooking has considerably emerged and many types of solar cookers have been reported in the literature [5] [6] [7] [8] [9]. Among them, the most commercial cookers are box type and concentrating type solar cookers [10] [11]. However, these cookers are limited because of solar energy intermittence. To enhance the performance and overcome the limitation issue of the box type solar cooker, a particular unit could be integrated for the thermal energy storage. Similarly, existing solar cookers with integrated storage unit are reported in the literature [11]-[18]. From these studies, it is clear that latent and sensible heat storage are the main modes of heat storage in solar cookers. While parameters such as cost, complexity of the storage system and availability of storage material have to be taken into account, sensible storage is an interesting option. Also, the use of locally available thermal energy storage materials, like vegetable oil, for enhancing the performance of solar cookers is rather limited. However, this could allow the development of cheaper and more efficient solar cookers. In this research work, Jatropha oil is used as heat storage material in a box type solar cooker. The objective of this work is to analyze the performance of a solar cooker using Jatropha oil as heat storage material.

\section{Materials and Methods}

\subsection{Construction and Testing Method of the Device}

The designed solar box type consisted of two plywood boxes (outer and inner box) with double glazing panes spaced by $1.3 \mathrm{~cm}$ of air gap. They are separated with kapok wool, a vegetable insulator and locally available. The thickness of insulation at the bottom of the cooker is $6 \mathrm{~cm}$ and the angle of inclination of the opening surface with respect to the horizontal is $13^{\circ}$. The storage unit is equipped with fins to improve the heat transfer between the storage oil and the absorber as shown in Figure 1, while Figure 2 shows the scheme of the device. The detailed parameters of the design solar cooker for the present studies are presented in Table 1.

The thermo-physical proprieties of Jatropha oil are given in Table 2.

\subsection{Performance Assessment}

The evaluation of the performance of the solar cooker is based on the results of the various tests carried out.

The cooking power and the efficiency of the solar cooker are calculated from a heating test result using Equation (1) [20].

$$
P=\frac{(m c)_{w}\left(T_{w_{f}}-T_{w_{i}}\right)}{\Delta t}=\frac{(m c)_{w}\left(T_{w_{f}}-T_{w_{i}}\right)}{600}
$$

The energy effiency of the solar cooker is calculated according to Equation (2) [21]. 


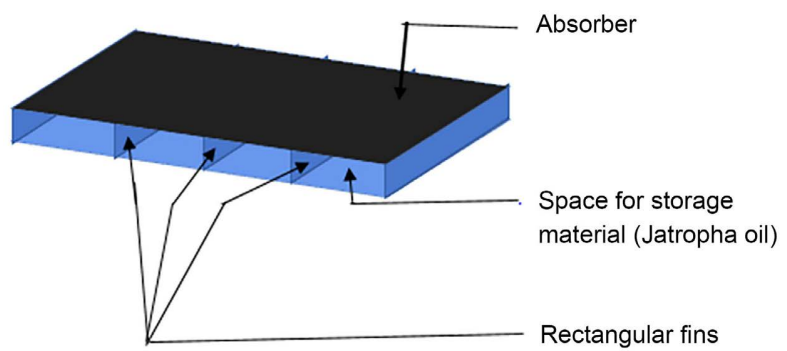

Figure 1. Storage unit.

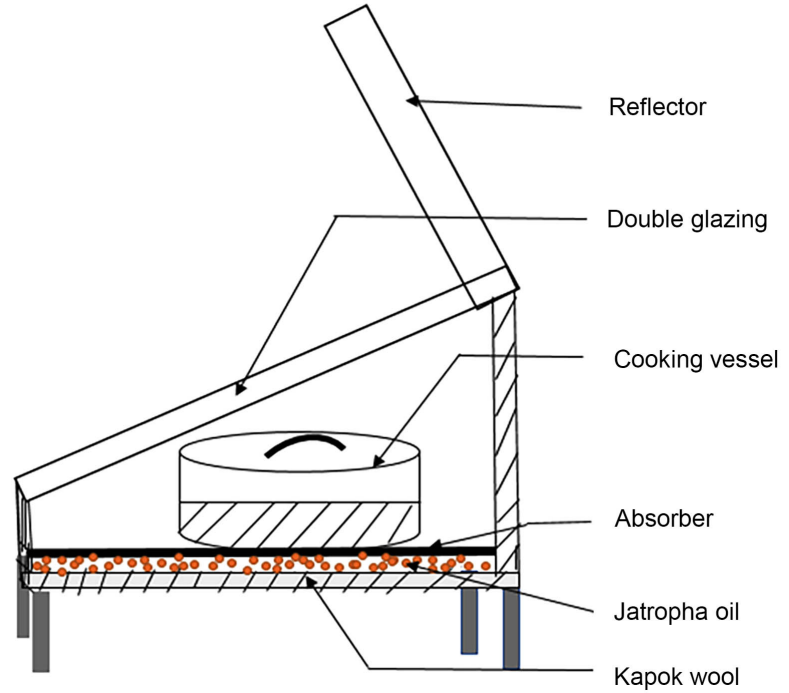

Figure 2. Scheme of the device.

Table 1. Design parameters of the box type solar cookers.

\begin{tabular}{ccc}
\hline Component & Dimension & Material \\
\hline Inner box & $600 \mathrm{~mm} \times 500 \mathrm{~mm} \times 130 \mathrm{~mm} \times 268.5 \mathrm{~mm}$ & Plywood \\
Outer box & $660 \mathrm{~mm} \times 560 \mathrm{~mm} \times 190 \mathrm{~mm} \times 328.5 \mathrm{~mm}$ & Plywood \\
Double glazing & $615.8 \mathrm{~mm} \times 500 \mathrm{~mm}$ & $4 \mathrm{~mm}$ thick glass \\
Reflector & - & S-Reflect \\
Absorber plate & $600 \mathrm{~mm} \times 500 \mathrm{~mm}$ & Black coated aluminum \\
Cooking pots & Diameter: $200 \mathrm{~mm}$ Height: $100 \mathrm{~mm}$ & Aluminum \\
Jatropha oil & 5 liters & - \\
\hline
\end{tabular}

Table 2. Thermo-physical proprieties of Jatropha oil [19].

\begin{tabular}{cc}
\hline Conductivity $(\mathrm{W} / \mathrm{m} \cdot \mathrm{K})$ & $k(T)=2.8 \times 10^{-7} T^{2}-2.258 \times 10^{-4} T+0.1736$ \\
Heat capacity $(\mathrm{kJ} / \mathrm{kg} \cdot \mathrm{K})$ & $c_{p}(T)=2.262 \times 10^{-9} T^{4}-10.423 \times 10^{-7} T^{3}+12.947 \times 10^{-5} T^{2}$ \\
& $+0.441 \times 10^{-3} T+1.9608$ \\
Dynamic viscosity (Pa.s) & $\mu(T)=32.867 T^{-1,8371}$ \\
Density $\left(\mathrm{kg} / \mathrm{m}^{3}\right)$ & $\rho(T)=-0.7392 T+933.47$
\end{tabular}




$$
\eta=\frac{(m c)_{w}\left(T_{w_{f}}-T_{w_{i}}\right)}{A_{c} I_{G} \Delta t}
$$

The charge and discharge efficiency are calculated using Equations (3) and (4) respectively [22] [23].

$$
\begin{gathered}
\varepsilon_{c h}=\frac{T_{c h}-T_{i n i}}{T_{\text {inlet }}-T_{\text {ini }}} \\
\varepsilon_{\text {dis }}=\frac{E_{\text {out }}}{E_{c h}}
\end{gathered}
$$

From Equations (3) and (4), the thermal storage global efficiency is calculated using Equation (5):

$$
\eta_{\text {storage }}=\varepsilon_{\text {ch }} \varepsilon_{\text {disch }}
$$

\section{Results and Discussion}

\subsection{Stagnation Test}

Figure 3 presents evolution of the absorber and the storage oil temperature and the global solar irradiation during the day of 08 April 2020.

The temperature of the absorber increases from $58.8^{\circ} \mathrm{C}$ at 9:07 am to $107.1^{\circ} \mathrm{C}$ at 10:37 am and reaches the stagnation temperature of $157.7^{\circ} \mathrm{C}$ at $14: 00 \mathrm{pm}$ with a solar irradiation of $851.71 \mathrm{~W} \cdot \mathrm{m}^{2}$. The maximum global solar radiation is $963.49 \mathrm{~W} / \mathrm{m}^{2}$ reached at 11:36 am. The time difference between the stagnation temperature and the maximum global solar radiation is due to the high thermal inertia of the solar cooker with heat storage. The temperature of the absorber remains above $110^{\circ} \mathrm{C}$ for almost seven (7) hours. This indicates that the solar cooker with storage unit reaches temperatures of the same order as the one without storage and maintains cooking temperatures for a long duration.

\subsection{Cooking Power and Efficiency}

Figure 4 presents the results of a heating test of $2 \mathrm{~kg}$ of water during the day of 24 December 2020.

Two load tests were carried out successively after the cooker has been preheated. The first load reached a temperature of $81^{\circ} \mathrm{C}$ in 2 hours 20 minutes under global solar radiation, varying between 401.72 and $743.18 \mathrm{~W} \cdot \mathrm{m}^{-2}$. The second test reached a temperature of $80.1^{\circ} \mathrm{C}$ in 1 hour and 50 minutes under global solar radiation which varies from 606.88 to $261.11 \mathrm{~W} \cdot \mathrm{m}^{-2}$. This clearly indicates that the developed solar cooker can be used twice a day. After introducing the second charge, the storage temperature remains above that of the absorber. In addition, between 14:28 pm and 15:48 pm, the temperature of the absorber and that of the water increases while the storage temperature and solar radiation decrease. This could be explained by the destocking of the energy recovered by the Jatropha oil and which enables the perfect operation of the cooker during sunset. 


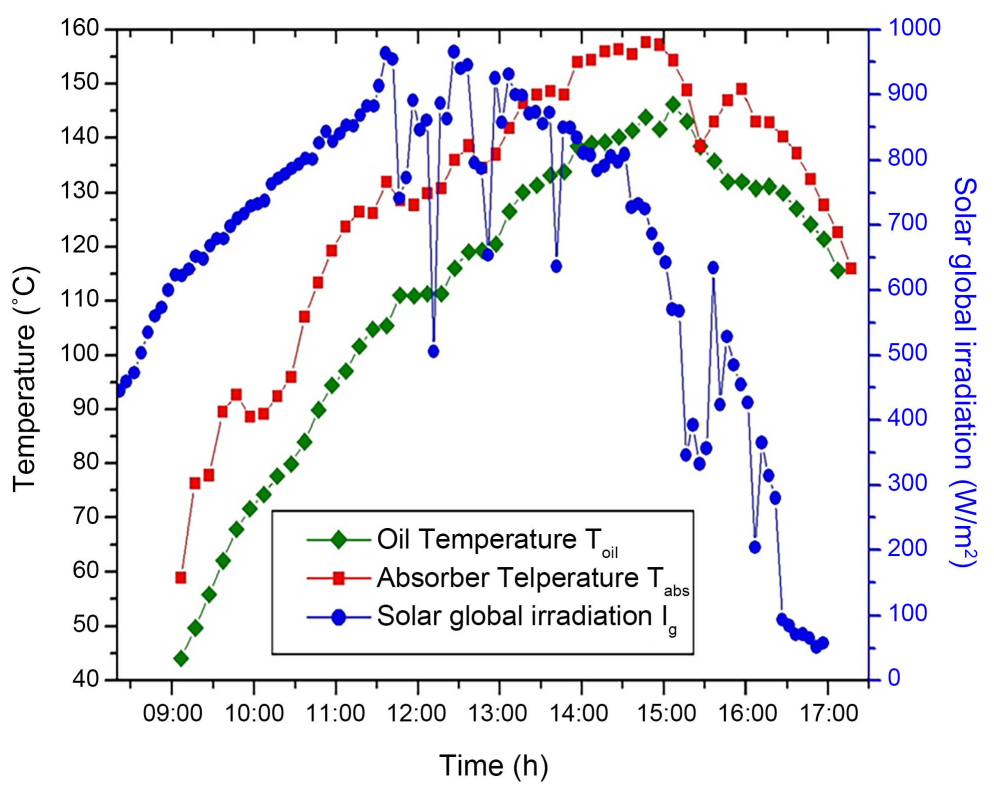

Figure 3. Temporal evolution of different components temperature.

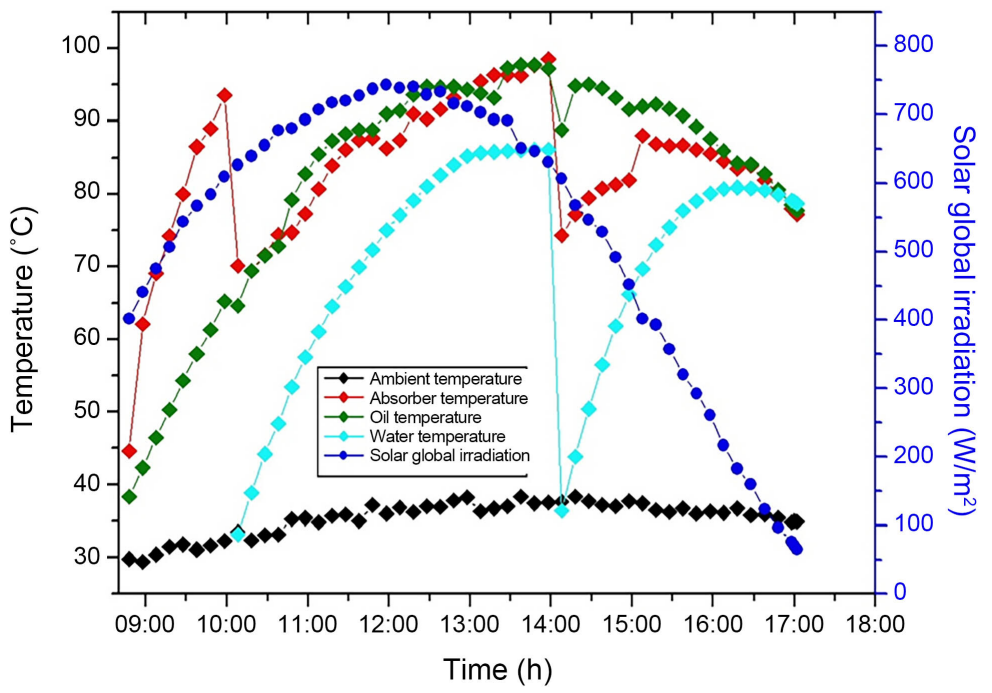

Figure 4. Water heating test.

Figure 5 presents the cooking power and thermal efficiency versus time of the solar cooker.

The maximum cooking power and thermal efficiency obtained during first charge are $78.4 \mathrm{~W}$ and $41.26 \%$ respectively. When the charge is introduced for the second time, the maximum cooking power and thermal efficiency obtained are $103.6 \mathrm{~W}$ and $58.78 \%$ respectively. This result can be explained by the fact that before introducing the charge, a significant amount of heat was already stored in the storage oil and thereafter transferred to the load introduced into the cooker. Sharma et al. [24], observed the same behavior of solar cooker integrating heat storage with a solar cooker using a phase change material as heat storage media. According to Öztürk [25], the efficiency of the box-type solar 
cooker without heat storage varies between $3.05 \%$ and $35.2 \%$. Thus, it can be seen from this work that the use of Jatropha oil as heat storage material can significantly enhance the performances of solar cookers.

\subsection{Charge and Discharge}

Figure 6 shows the behavior of the solar cooker with storage during a charge and discharge cycle. For this test, the solar cooker is exposed to the sun until it reaches its stagnation temperature, and then the external reflector is folded over the collecting surface to prevent the solar cooker from collecting solar radiation.

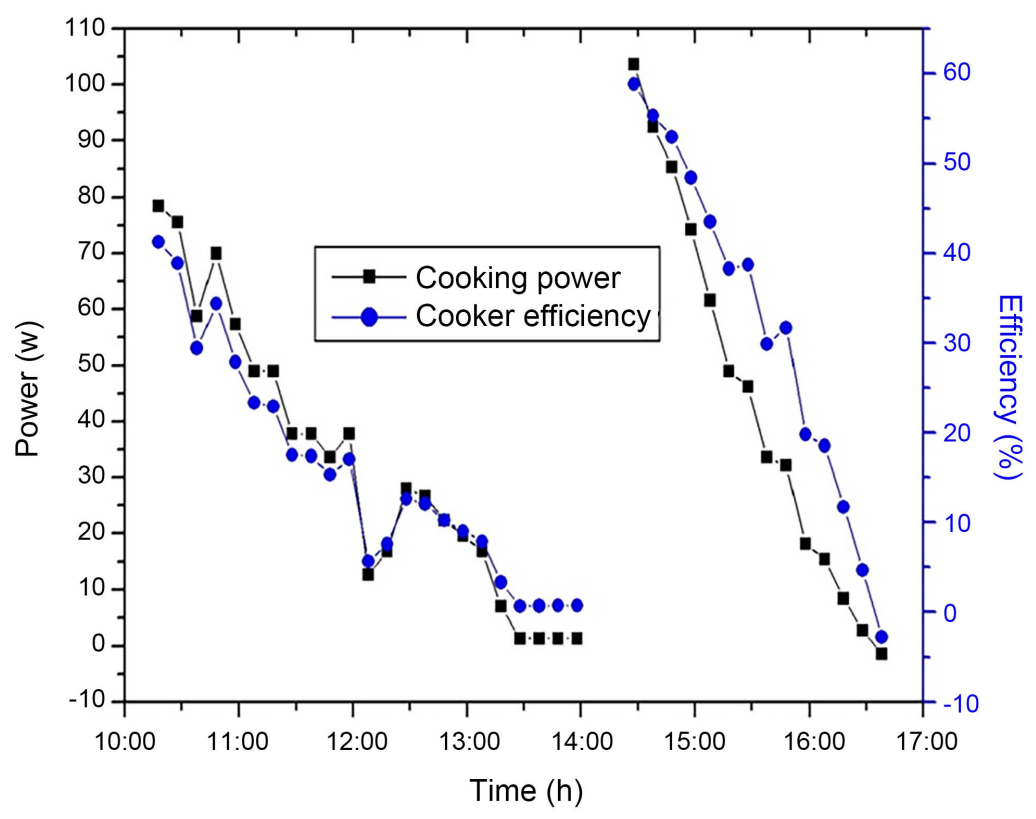

Figure 5. Cooking power and cooker efficiency.

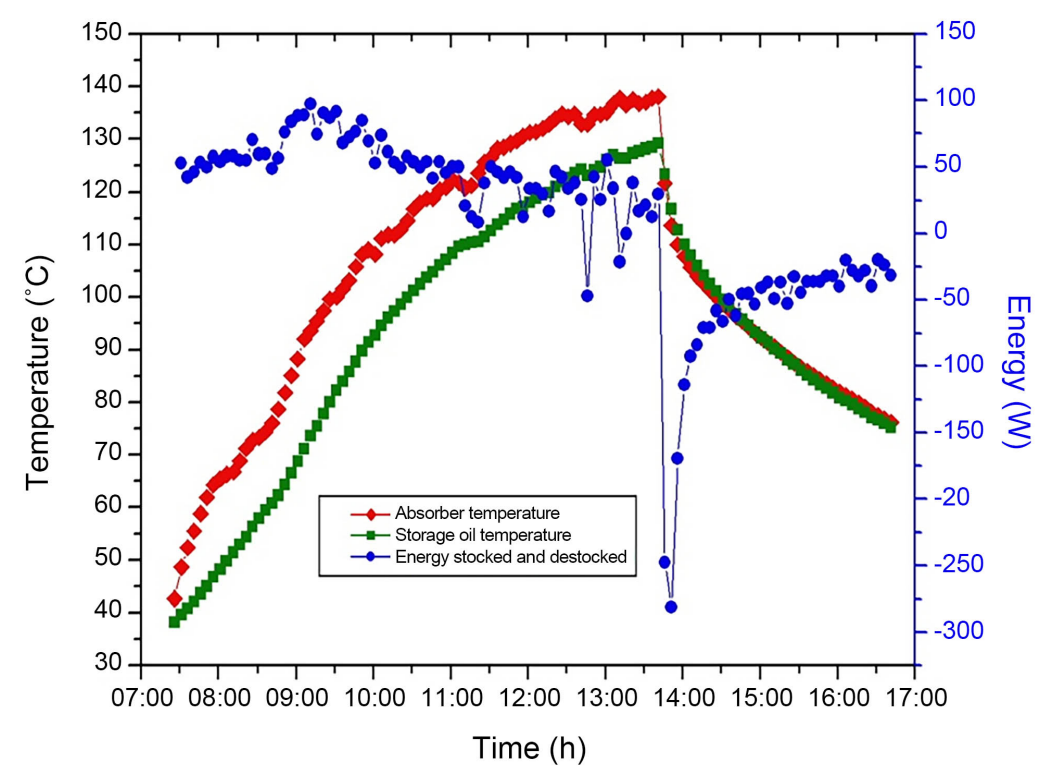

Figure 6. Charge and discharge test. 
Table 3. Charging and discharging efficiency.

\begin{tabular}{rrrrrrr}
\hline $\begin{array}{r}T_{\text {ch }} \\
\left({ }^{\circ} \mathrm{C}\right)\end{array}$ & $\begin{array}{c}T_{\text {inlet }} \\
\left({ }^{\circ} \mathrm{C}\right)\end{array}$ & $\begin{array}{r}T_{\text {ini }} \\
\left({ }^{\circ} \mathrm{C}\right)\end{array}$ & $\begin{array}{c}E_{\text {ch }} \\
(\mathrm{kW})\end{array}$ & $\begin{array}{c}E_{\text {out }} \\
(\mathrm{kW})\end{array}$ & $\begin{array}{c}\mathcal{E}_{c h} \\
(\%)\end{array}$ & $\begin{array}{c}\mathcal{E}_{\text {disch }} \\
(\%)\end{array}$ \\
\hline 129.2 & 138 & 38.2 & 2.293 & 2.236 & 91.18 & 97.51
\end{tabular}

After closing the cooker, the temperature of the absorber plate drops abruptly from the stagnation temperature of $138^{\circ} \mathrm{C}$ to $121.6^{\circ} \mathrm{C}$ and the temperature of the storage oil drops from $129.2^{\circ} \mathrm{C}$ to $123.6^{\circ} \mathrm{C}$. The sudden drop in the temperature of the absorber is due to the fact that when the cooker is closed, the thermal energy stored in the absorber is emitted towards the cover which behaves like a black body. The resulting drop in oil temperature indicates a release of energy to the absorber. Figure 6 shows that the amount of energy destocked to stabilize the temperature of the absorber is $280.79 \mathrm{~W}$ (or $84.237 \mathrm{~kJ}$ ).

Table 3 presents the value of the charging and discharging efficiency.

The charge and discharge efficiencies are $91.18 \%$ and $97.51 \%$, respectively, while thermal storage global efficiency is $88.91 \%$. These results reflect the good heat transfer that exists between the oil storage and the absorber. This is attributed to the fins attached to the absorber for heat exchange improvement. Also, it appears that nearly $90 \%$ of the energy lost at the bottom of the cooker is recovered and thereafter transferred to the cooker during intermittent times. This shows that sensible heat storage with Jatropha oil could enhance the solar cooker performance during cloudiness while cooking.

\section{Conclusion}

This work has shown that the cooker using Jatropha oil as storage material reaches a maximum temperature of $157.7^{\circ} \mathrm{C}$ with relatively high power and efficiency. This performance is achieved thanks to the Jatropha oil which recovers nearly $90 \%$ of the heat lost at the bottom of the solar cooker and transfers it back to the cooker. Also, the storage unit integrated into the cooker protects it against atmospheric perturbations (cloudy weather).

\section{Conflicts of Interest}

The authors declare no conflicts of interest regarding the publication of this paper.

\section{References}

[1] Omara, A.A.M., Abuelnuor, A.A.A., Mohammed, H.A., Habibi, D. and Younis, O. (2020) Improving Solar Cooker Performance Using Phase Change Materials: A Comprehensive Review. Solar Energy, 207, 539-563. https://doi.org/10.1016/j.solener.2020.07.015

[2] UNDP (2012) Integrating Energy Access and Employment Creation to Accelerate Progress on the MDGs in Sub-Saharan Africa.

[3] Bildirici, M. and Özaksoy, F. (2016) Woody Biomass Energy Consumption and Eco- 
nomic Growth in Sub-Saharan Africa. Procedia Economics and Finance, 38, 287-293. https://doi.org/10.1016/S2212-5671(16)30202-7

[4] Otte, P.P. (2013) Solar Cookers in Developing Countries-What Is Their Key to Success? Energy Policy, 63, 375-381. https://doi.org/10.1016/j.enpol.2013.08.075

[5] Joshi, S.B. and Thakkar, H. (2017) Solar Cooker-A Review. 6th Solar Cooker International World Conference. (Available Online, 2021)

[6] Yettou, F., Azoui, B., Malek, A., Gama, A. and Panwar, N.L. (2014) Solar Cooker Realizations in Actual Use: An Overview. Renewable and Sustainable Energy Reviews, 37, 288-306. https://doi.org/10.1016/j.rser.2014.05.018

[7] Rathore, M.M. and Warkhedkar, R.M. (2015) A Review of Solar Cookers. International Journal of modern Trends in Engineering and Research, 2, 1997-2004.

[8] Aramesh, M., Ghalebani, M., Kasaeian, A. and Zamani, H. (2019) A Review of Recent Advances in Solar Cooking Technology. Renewable Energy, 140, 419-435. https://doi.org/10.1016/j.renene.2019.03.021

[9] Cuce, E. and Cuce, P.M. (2013) A Comprehensive Review on Solar Cookers. Applied Energy, 102, 1399-1421. https://doi.org/10.1016/j.apenergy.2012.09.002

[10] Waheed, A., Ahmed, A. and Zahedi, G. (2012) Greener Energy: Issues and Challenges for Pakistan-Solar Energy Prospective. Renewable and Sustainable Energy Reviews, 16, 2762-2780. https://doi.org/10.1016/j.rser.2012.02.043

[11] Muthusivagami, R.M., Velraj, R. and Sethumadhavan, R. (2010) Solar Cookers with and without Thermal Storage-A Review. Renewable and Sustainable Energy Reviews, 14, 691-701. https://doi.org/10.1016/j.rser.2008.08.018

[12] Domanski, R., El-Sebaii, A.A. and Jaworski, M. (1995) Cooking during Off-Sunshine Hours Using PCMs as Storage Media. Energy, 20, 607-616. https://doi.org/10.1016/0360-5442(95)00012-6

[13] Hussein, H.M.S., El-Ghetany, H.H. and Nada, S.A. (2008) Experimental Investigation of Novel Indirect Solar Cooker with Indoor PCM Thermal Storage and Cooking Unit. Journal of Hazardous Materials, 157, 480-489.

[14] Bhatt, V.D. and Gohil, K. (2012) Performance Evaluation of Solar Cooker Using some [N+4444] Based Ionic Liquids as Thermal Energy Storage Materials. Advanced Materials Letters, 4, 277-282.

[15] Saxena, A., Lath, S. and Tirth, V. (2013) Solar Cooking by Using PCM as a Thermal Heat Storage. MIT International Journal of Mechanical Engineering, 3, 91-95.

[16] Mawire, A. (2015) Solar Thermal Energy Storage for Solar Cookers. In: Sørensen, B., Ed., Solar Energy Storage, Elsevier Ltd., Amsterdam, 327-358. https://doi.org/10.1016/B978-0-12-409540-3.00014-1

[17] Yuksel, N., Arabacigıl, B. and Avci, A. (2012) The Thermal Analysis of Paraffin Wax in a Box-Type Solar Cooker. Journal of Renewable and Sustainable Energy, 4, Article ID: 063126. https://doi.org/10.1063/1.4768547

[18] Arabacigil, B., Yuksel, N. and Avci, A. (2015) The Use of Paraffin Wax in a New Solar Cooker with Inner and Outer Reflectors. Thermal Science, 19, 1663-1671. https://doi.org/10.2298/TSCI121022031A

[19] Hoffmann, J.F. (2015) Stockage Thermique pour centrale solaire thermodynamique à concentration mettant en œuvre des matériaux naturels ou recyclés. Thèse de Doctorat, Université de Perpignan Via Domitia, Perpignan.

[20] American Society of Agricultural Engineers (2003) ASAE S580 JAN03: Testing and Reporting Solar Cooker Performance. (Available online, 2021)

[21] Saxena, A., Pandey, S.P. and Srivastav, G. (2011) A Thermodynamic Review on So- 
lar Box Type Cookers. Renewable and Sustainable Energy Reviews, 15, 3301-3318. https://doi.org/10.1016/j.rser.2011.04.017

[22] Mawire, A., Phori, A. and Taole, S. (2014) Performance Comparison of Thermal Energy Storage Oils for Solar Cookers during Charging. Applied Thermal Engineering, 73, 1323-1331. https://doi.org/10.1016/j.applthermaleng.2014.08.032

[23] Mawire, A. (2016) Performance of Sunflower Oil as a Sensible Heat Storage Medium for Domestic Applications. Journal of Energy Storage, 5, 1-9. https://doi.org/10.1016/j.est.2015.11.002

[24] Sharma, S.D., Iwata, T., Kitano, H. and Sagara, K. (2005) Thermal Performance of a Solar Cooker Based on an Evacuated Tube Solar Collector with a PCM Storage Unit. Solar Energy, 78, 416-426. https://doi.org/10.1016/j.solener.2004.08.001

[25] Öztürk, H.H. (2004) Second Law Analysis for Solar Cookers. International Journal of Green Energy, 1, 227-239. https://doi.org/10.1081/GE-120038754

\section{Nomenclature}

$\varepsilon_{c h}$ : charging efficiency

$\varepsilon_{\text {dis }}:$ discharging efficiency

$T_{c h}$ : instantaneous storage temperature $\left({ }^{\circ} \mathrm{C}\right)$

$T_{\text {ini }}$ : storage initial temperature $\left({ }^{\circ} \mathrm{C}\right)$

$T_{\text {inlet }}:$ inlet température $\left({ }^{\circ} \mathrm{C}\right)$

$E_{\text {out }}$ : energy distocked (W)

$E_{c h}:$ energy stocked (W)

$I_{G}$ :solar global irradiation $\left(\mathrm{W} / \mathrm{m}^{2}\right)$

$\Delta t=t_{2}-t_{1}$ : time interval from $T_{w_{i}}$ to $T_{w_{f}}(\mathrm{~s})$

$T_{w_{i}}:$ water initial temperature $\left({ }^{\circ} \mathrm{C}\right)$

$T_{w_{f}}$ : water final temperature $\left({ }^{\circ} \mathrm{C}\right)$

$m$ : water mass $(\mathrm{kg})$

c. specific heat capacity of water $(\mathrm{J} / \mathrm{kg} \mathrm{K})$

$P$ : cooking thermal power $(\mathrm{W})$

$\eta$ : energy efficiency of the cooker

$I_{G}$ : instantaneous solar irradiation $\left(\mathrm{W} / \mathrm{m}^{2}\right)$ over the time interval $\Delta t(\mathrm{~s})$

$A_{c}$ : opening area of the solar cooker $\left(\mathrm{m}^{2}\right)$ 